Paedagogia Christiana

2/28 (201 I) - ISSN 1505-6872

Józef M. Dotęga*

Warszawa

\title{
Nauki środowiskowe na początku XXI wieku
}

Artykuł prezentuje analizy dotyczące podstawowych terminów, pojęć, koncepcji, problematyki metodologicznej i merytorycznej ekofilozofii i sozologii. Problematyka sozologii skupiona jest wokół następujących zagadnień: koncepcji sozologii systemowej, epistemologii sozologii systemowej, metodologii sozologii systemowej; głównej problematyki sozologii systemowej i specyfiki badań z zakresu tej nauki. Trzecia część artykułu jest poświęcona naukom środowiskowym, wykładanym na uniwersytetach jako wykłady kursoryczne lub monograficzne. Jest to tylko rejestr tych nauk z krótką informacją merytoryczną i bibliograficzną.

Tekst tego artykułu jest ulepszoną wersją wcześniej drukowanych moich prac w „Studia Ecologiae et Bioethicae” i w książkach: Koncepcja sozologii systemowej; Zarys sozologii systemowej oraz w innych publikacjach.

\section{Ekofilozofia}

Termin ekofilozofia wszedł oficjalnie do słownika filozoficznego na VI Zjeździe Filozofii Polskiej w 1995 roku w Toruniu. Do sekcji „Ekofilozofia i filozofia życia” zgłoszono 29 referatów. Część z nich dotyczyła ekofilozofii. Od Zjazdu Toruńskiego termin ten zaczyna funkcjonować coraz

* Ks. prof. dr hab. Józef M. Dołęga, kierownik Katedry Ekofilozofii i Edukacji Ekologicznej w Instytucie Ekologii i Bioetyki na Wydziale Filozofii Chrześcijańskiej Uniwersytetu Kardynała Stefana Wyszyńskiego w Warszawie. 
częściej w tekstach publikowanych i w wykładach, znakiem tego są dwa numery „Ateneum Kapłańskiego” 138 (2002), z. 2, 139 (2002), z. 3, i cały szereg publikacji oraz wykłady kursoryczne i monograficzne w uniwersytetach i akademiach. Wprowadziły je: Uniwersytet Kardynała Stefana Wyszyńskiego, Uniwersytet Adama Mickiewicza, Uniwersytet Mikołaja Kopernika, Uniwersytet Warmińsko-Mazurski, Katolicki Uniwersytet Lubelski, Papieska Akademia Teologiczna, Uniwersytet Szczeciński, Uniwersytet Śląski, Uniwersytet w Białymstoku, Akademia Podlaska, Pomorska Akademia Pedagogiczna, Politechnika Lubelska, Politechnika Łódzka i inne. Szkoda, że ekofilozofia nie pojawiła się na VIII Polskim Zjeździe Filozoficznym (15-20 września 2008 roku) w Warszawie poza dwoma wykładami w różnych sekcjach.

\subsection{Analiza semantyczna terminu ekofilozofia}

W analizie semantycznej terminu ekofilozofia wyjdziemy od znakomitego tekstu Antoniego B. Stępnia na temat filozofii, zamieszczonego w Stowniku pojęć filozoficznych ${ }^{1}$.

1. Filozofia - jak wiadomo termin ten pochodzi z języka greckiego:

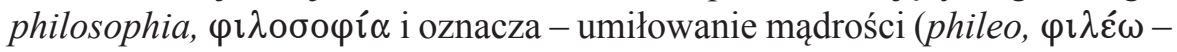

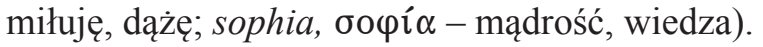

Termin ten posiada wiele odcieni znaczeń, a mianowicie:

- znaczenie najogólniejsze: wiedza o świecie, wiedza dotycząca bytu jako bytu, wiedza dotycząca przedmiotu (przedmiotów), wiedza dotycząca źródeł i granic poznania;

- znaczenie światopoglądowe: oznacza światopogląd zapewniający osobie ludzkiej orientację w świecie i umożliwiający życie rozumne;

- znaczenie naukowotwórcze: oznacza teorie wiedzy naukowej.

Termin sophia, бoфí $\alpha$ pierwotnie oznaczał wszelkiego rodzaju teoretyczną i praktyczną mądrość, którą mędrzec (sophos, oọós) wyróżniał się wśród przeciętnych ludzi. Nadano temu słowu znaczenie przede wszystkim teoretyczne, które umożliwiało zdobycie jakiejś umiejętności (techne,

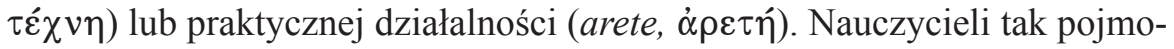

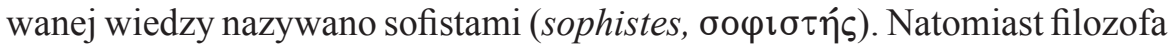

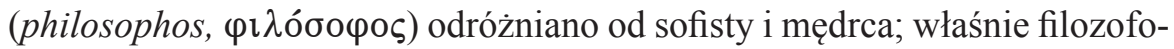
wie powinni metodycznie dążyć do zdobycia mądrości, do zdobycia wiedzy o tym, co naprawdę istnieje. W związku z tym w myśli europejskiej możemy wyróżnić przede wszystkim dwa zasadnicze znaczenia terminu filozofia:

${ }^{1}$ W. Krajewski (red.), Stownik pojęć filozoficznych, Warszawa 1996, s. 57-60. 
$1^{0}$ Filozofia jako najogólniejsza nauka o świecie lub zbiór kilku ogólnych nauk filozoficznych;

$2^{0}$ Filozofia jako światopogląd przede wszystkim mający praktyczne znaczenie.

Oba te rozumienia filozofii nie są przeciwstawne, a można je rozumieć jako ujęcia komplementarne.

2. Ekofilozofia - termin składa się z trzech wyrażeń greckich:

- oikos, olкоৎ - oznacza: środowisko, dom, mieszkanie, siedzibę, mienie rodzinne, gospodarstwo, rodzinę;

- phileo, $\varphi \imath \lambda \varepsilon ́ \omega-$ oznacza: miłuję, dążę;

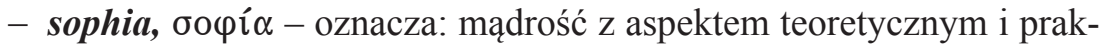
tycznym.

Zatem ekofilozofia, w najogólniejszym rozumieniu, jest nauką filozoficzną o środowisku. Inaczej mówiąc, ekofilozofia jest nauką filozoficzną o środowisku przyrodniczym i społecznym, czyli o ekosystemie ziemskim i jego otoczeniu z aspektami teoretycznymi i praktycznymi. Krócej mówiąc: ekofilozofia jest nauką o ekosystemie i jego otoczeniu. Określenia te zawierają terminy, które należy wyjaśnić, a mianowicie:

- nauka filozoficzna: charakterystyka tej nauki zawarta jest w epistemologii i metodologii filozofii, analogicznie do filozofii należy wypracować epistemologię i metodologię ekofilozofii, uwzględniając specyfikę w przyjmowanych koncepcjach tej nauki;

- środowisko: rozumiemy w ujęciu całościowym, czyli ze wszystkimi sferami, w których toczy się proces życia i istnieje człowiek, a mianowicie: atmosferą, hydrosfrą, litosferą, kosmosferą, biosferą, antroposferą;

- system $(\sigma u ́ \sigma \tau \eta \mu \alpha)$ : termin ten jest pomocny w opisie nie tylko różnorakich podsystemów przyrodniczych, ale również w opisie podsystemów społecznych, ekonomicznych, technicznych, przemysłowych itp. Wielki system to jeden wielki obiekt sterowania, który według Mieczysława Lubańskiego ${ }^{2}$ charakteryzuje się następującymi właściwościami:

- system ten składa się z podsystemów, które można wyróżnić i opisać;

- każdy z podsystemów ma własny cel działania, a jego efektywność może być oceniana w zależności od procesu sterowania;

${ }^{2}$ M. Lubański, Informacja - system, w: M. Heller, M. Lubański, S. W. Ślaga, Zagadnienia filozoficzne wspótczesnej nauki. Wstęp do filozofii przyrody, Warszawa 1982, s. 29-31; Z. Kierzkowski, Elementy informatyki. Technika, metody zastosowania, Warszawa 1976, s. 497-498. 
- cały system ma ogólny cel działania, a jego efektywność ocenia się na podstawie działania podsystemów;

- w podsystemach, jak też między nimi, zachodzą liczne sprzężenia;

- w systemie istnieje hierarchiczna struktura sterowania;

- rozbudowana sieć informacyjna gwarantuje celowe funkcjonowanie i optymalizację systemu;

- w systemie obserwuje się współdziałanie ludzi, wytworów człowieka i środowiska przyrodniczego - wszystkie te elementy systemu tworzą środowisko;

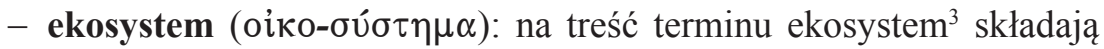
się następujące elementy:

- organizmy żywe (biosfera) - czynniki biotyczne;

- i człowiek z całą antroposferą;

- oraz czynniki abiotyczne - atmosfera, hydrosfera, litosfera, kosmosfera, magnetosfera.

W poznaniu naukowym możemy prowadzić badania małych ekosystemów o dużej złożoności oraz można rozpatrywać wielki ekosystem ziemski, uwzględniając wszystkie oddziaływania wewnętrzne oraz wpływ otoczenia na ten system, czyli najbliższego otoczenia kosmicznego Ziemi i Kosmosu;

- otoczenie: pojęcie otoczenia jest związane z rozumieniem systemu, a przez system ${ }^{4}$ rozumiemy zespół różnych elementów wzajemnie ze sobą powiązanych, na siebie oddziaływujących i stanowiących pod pewnym względem całość. Określenie to nawiązuje do filologiczne-

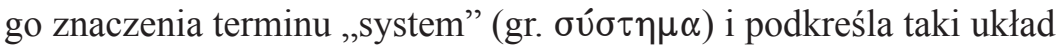
elementów, który tworzy pewną całość uwarunkowaną stałym ładem jego części składowych w świecie realnym lub w sferze poznania ludzkiego. System stanowi całość, w której elementy są powiązane z sobą relacjami oddziaływania i stanowią jego strukturę. Każdy system otwarty ma swoje otoczenie. W przyrodzie i w poznaniu ludzkim

${ }^{3}$ Por. A. M. Mannion, Zmiany środowiska Ziemi. Historia środowiska przyrodniczego i kulturowego, Warszawa 2001, s. 15-17.

${ }^{4}$ Por. A. Podsiad, Z. Więckowski, Mały stownik terminów i pojęć filozoficznych, Warszawa 1983, s. 380-381; J. Tokarski (red.), Stownik wyrazów obcych, Warszawa 1971, s. 723; J. Bocheński, O systemie, Wykład wygłoszonych w ATK 1987-11-05, „Studia Philosophiae Christianae" 2 (1988), s. 235-248; Problemy metodologii badań systemowych, Warszawa 1973; S. Młynarki, Elementy teorii systemów i cybernetyki, Warszawa 1974; G. J. Klir (red.), Ogólna teoria systemów, Warszawa 1976; W. Sadowski, Podstawy ogólnej teorii systemów. Analiza logiczno-metodologiczna, Warszawa 1978; L. von Bartalanffy, Ogólna teoria systemów. Podstawy, rozwój, zastosowania, Warszawa 1984; M. Lubański, Informacja, s. 14-70; W. Gasparski i D. Miller (red.), Nauka-technika-system, Wrocław 1981. 
występują przede wszystkim systemy otwarte. Otoczenie jest to rzeczywistość, która wchodzi lub może wchodzić w relacje z systemem, głównie polegające na wymianie energii i informacji;

- aspekt teoretyczny ekofilozofii oznacza poznanie teoretyczne ekosystemu na różnych poziomach złożoności;

- aspekt praktyczny ekofilozofii oznacza różnego rodzaju zastosowania nauki w ekosystemie, na przykład sozotechnikę i inne.

\subsection{Koncepcje ekofilozofii}

Ekofilozofia - jako nowa nauka filozoficzna ma już bogatą i zróżnicowaną literaturę na temat teorii, metodologii i koncepcji tej nauki. W tym miejscu nie dokonujemy szczegółowej analizy poszczególnych ujęć ekofilozofii, a tylko prezentujemy ich rejestr, krótką charakterystykę i podstawową literaturę.

1. Ekofilozofia jako filozofia ekologii ${ }^{5}$ - wyrażenie „filozofia ekologii” w podstawowym znaczeniu funkcjonuje w filozofii nauki i oznacza teorię i metodologię ekologii. W ostatnich dziesiątkach lat XX wieku i na początku XXI wieku wyrażenie to zawiera w swojej treści i zakresie wiele elementów z szeroko rozumianych zagadnień filozoficznych i ochrony środowiska. Przykładem takich ujęć są prace Zbigniewa Hulla z Uniwersytetu Warmińsko-Mazurskiego.

2. Ekofilozofia jako ekologia człowieka ${ }^{6}$ - wyrażenie ,ekologia człowieka" zastosowane przez Napoleona Wolańskiego do określenia syntezy

${ }^{5}$ Z. Hull, Filozofia ekologii jako nowa dziedzina filozofowania, w: W. Tyburski (red.), Ekofilozofia i bioetyka. Materiały VI Polskiego Zjazdu Filozoficznego w Toruniu 5-9 września 1995 r., Sekcja Bioetyki i Ekofilozofii, Toruń 1996, s. 9-29; por. A. Papuziński, Metafizyczne dziedzictwo nauki jako problem filozofii ekologii, w: W. Tyburski (red.), Ekofilozofia, s. 29-42; Z. Hull, Problemy filozofii ekologii, w: A. Papuziński (red.), Wprowadzenie do filozoficznych problemów ekologii, Bydgoszcz 1999, s. 55-96; tenże, O dwóch sposobach pojmowania i uprawiania filozofii ekologii. Z filozofii nauk ekologicznych, w: J. M. Dołęga, J. W. Czartoszewski, A. Skowroński (red.), Ochrona środowiska społeczno-przyrodniczego w filozofii i teologii, Warszawa 2001, s. 38-45; J. M. Dołęga, Z filozofii nauk ekologicznych, w: J. M. Dołęga, J. W. Czartoszewski, A. Skowroński (red.), dz. cyt., s. 25-37.

${ }^{6}$ N. Wolański, Glossary of terms for human ecology, Warsaw 1990; tenże (red.), Czynniki rozwoju człowieka. Wstęp do ekologii człowieka, Warszawa 1972; A. Horst, Ekologia człowieka, Warszawa 1976; B. Kuźnicka (red.), Ekologia człowieka. Historia współczesności, Warszawa 1995; N. Wolański, Nowoczesność jako sprawność w przystosowaniu człowieka do środowiska, „Prakseologia” 1-2 (1992), s. 105-127; S. Jaromi, Ecologia humana - chrześcijańska odpowiedź na kryzys ekologiczny, Kraków 2004; J. W. Czartoszewski, J. M. Dołęga (red.), Ekologia rodziny ludzkiej, „Episteme” 7 (2000); B. Campbell, Ekologia człowieka. 
wyników badań naukowych z zakresu antropologii przyrodniczej, ekologii i nauk medycznych. W ujęciu tym jest duży zakres zagadnień i refleksji antropologicznych o charakterze filozoficznym. Ponadto na początku XXI wieku pojawiły się nowe wyrażenia, ujmujące istotne obszary działalności człowieka związanej ze środowiskiem, a mianowicie: ekologia rodziny ludzkiej, ecologia humana, ekologia społeczna.

3. Ekofilozofia jako ekologia humanistyczna ${ }^{7}-$ w zapowiedzi Stanisława Zięby - ma prowadzić badania naukowe nad życiem człowieka w jego aspekcie specyficznie ludzkim i osobowym.

4. Ekofilozofia jako ekologia głęboka ${ }^{8}$ - koncepcja ta zawiera zagadnienia filozoficzne nie tylko w założeniach, ale również w rozwiązaniach problemów szczegółowych, związanych z kryzysem i katastrofami ekologicznymi oraz z kryzysem moralnym człowieka.

5. Ekofilozofia jako filozofia ekologiczna ${ }^{9}$ - wyrażenie wprowadzone przez Henryka Skolimowskiego; w zestawieniu z takim wyrażeniem, jak „filozofia logiczna”, które już funkcjonuje w słowniku naukowym, może z biegiem czasu uprawomocnić się w języku filozoficznym. Koncepcja ta rozwijana jest przez działalność Towarzystwa Przyjaciół Ekofilozofii oraz wielu autorów, którzy są zafascynowani wykładem i ujęciem problematyki ekofilozoficznej przez Henryka Skolimowskiego.

Historia naszego miejsca w przyrodzie od prehistorii do czasów wspótczesnych, Warszawa 1995; D. Kiełczewski, Ekologia społeczna, Białystok 1998.

${ }^{7}$ Por. S. Zięba, Ku ekologii humanistycznej, „Człowiek i Przyroda” 1 (1994), s. 7-13; L. Pawłowski, S. Zięba (red.), Humanizm ekologiczny, vol. 1: Jakiej filozofii potrzebuje ekologia, ochrona przyrody a ochrona człowieka, Lublin 1992; W. Tyburski, Pojednać się z Ziemia. W kręgu zagadnień humanizmu ekologicznego, Toruń 1993; I. Pollo, Z. M. Kozak (red.), Humanizm ekologiczny, vol. 4B: Technika szansq czy zagrożeniem (aspekty techniczne), Lublin 1996; S. Zięba, Natura i człowiek w ekologii humanistycznej, Lublin 1998; tenże, Historia ekologii, Lublin 2004.

${ }^{8}$ B. Devall, G. Sessions, Ekologia głęboka. Żyć w przekonaniu, iż Natura coś znaczy, Warszawa 1994; R. Bzdak, Problem możliwości teoretycznego uzasadniania głębokiej ekologii, w: J. Dębowski (red.), Człowiek i środowisko - humanistyka i ekologia. Prace Olsztyńskiego Sympozjum Ekologicznego, Olsztyn 5-6 maja 1994 roku, Olsztyn 1995, s. 91-96; A. Synowiecki, Człowiek - z ziemi wzięty, „Człowiek i Przyroda” 1 (1994), s. 41-92; K. Waloszczyk, Kryzys ekologiczny w świetle ekofilozofii, Łódź 1996, s. 228-241.

9 Por. H. Skolimowski, Filozofia żyjąca. Ekofilozofia jako drzewo życia, Warszawa 1992; D. Kiełczewski, Wybrane nurty filozofii ekologicznej, Białystok 1993, s. 5-32; K. Waloszczyk, dz. cyt., s. 207-228; H. Skolimowski, Medytacje, Wrocław 1991; tenże, Wizje Nowego Millenium, Kraków 1999; H. Skolimowski, J. K. Górecki, Zielone oko kosmosu. Wokót ekofilozofii w rozmowie i esejach, Wrocław 2003. 
6. Ekofilozofia jako ekozofia $\mathrm{T}^{10}$ - jest budowana na filozofii związanej z kierunkami panteistycznymi - zarówno historycznymi, jak i współczesnymi, oraz w oparciu o założenia ekologii głębokiej.

7. Ekofilozofia jako filozofia kryzysu ekologicznego ${ }^{11}$ - orientacja ta dotyczy przede wszystkim zagadnień etycznych, prawnych, politycznych i ekonomicznych, związanych z kryzysem ekologicznym oraz ekologii jako nowego paradygmatu polityki.

8. Ekofilozofia jako ujęcie systemowo-informacyjne ekorozwoju ${ }^{12}$ ujęcie to zawarte w pracach Lesława Michnowskiego znajduje uzasadnienie i zastosowanie w prognozach rozwoju człowieka i w założeniach zrównoważonego rozwoju.

9. Ekofilozofia jako ekologia uniwersalistyczna ${ }^{13}$ - pojawia się w kontekście ujęć filozofii uniwersalistycznej, a inaczej mówiąc uniwersalizmu, jako metafilozofii, prezentowanej w Polsce między innymi w pracach Janusza Kuczyńskiego.

10. Ekofilozofia jako praktyczna filozofia przyrody ${ }^{14}$ - ujęcie to akcentuje zagadnienia przede wszystkim praktyczne i bioetyczne związane z kryzysem ekologicznym. Koncepcja ta w literaturze przedmiotowej w Polsce prezentowana jest między innymi przez Zbigniewa Łapko i Annę Lemańską.

11. Ekofilozofia jako część filozofii przyrody ${ }^{15}$ - koncepcja ta jest związana z ujęciem filozofii przyrody orientacji arystotelesowsko-tomistycznej,

${ }^{10}$ Por. B. Devall, G. Sessions, dz. cyt., s. 289-293; M. Ryszkiewicz, Matka Ziemia w przyjaznym kosmosie. Gaja i zasada antropiczna w dziejach myśli przyrodniczej, Warszawa 1994; B. Jakubowska, Gaja - wiecznie żywa, „Studia Ecologiae et Bioethicae” 1 (2003), s. 593-604.

${ }^{11}$ Por. E. Phillips, Crisi in Atmosphere: The greenhause factor, Phoenix 1990; V. Hosle, Philos ophie der okologischen Krise, München 1994; Z. Piątek, Filozoficzne korzenie kryzysu środowiskowego, w: J. Dębowski (red.), dz. cyt., s. 43-50.

${ }_{12}$ L. Michnowski, Jak żyć? Ekorozwój albo..., Białystok [brw]; B. Zaufal, M. Białecka, Ekorozwój szansa przetrwania cywilizacji. Materiały z konferencji PKE, t. 3, Kraków 1986; L. Michnowski, Czy regres człowieczeństwa?, Warszawa 1999.

${ }_{13}$ Por. J. Kuczyński, Udomowienie Ziemi. Interpretacja Leszka Kołakowskiego projektu metanoi, w: tenże (red.), Ziemia naszym domem, Warszawa 1996, s. 155-178; por. tenże, Wstęp do uniwersalizmu, t. 1: Ogrodnicy świata, Warszawa 1998; t. 2: Młodość Europy i wieczność Polski, Warszawa 1999.

${ }^{14}$ Por. Z. Łepko, Ku ekofilozofii, „Studia Philosophiae Chistianae” 1 (1994), s. 21-34; tenże, Ekofilozofia jako praktyczna filozofia przyrody, w: J. Dębowski (red.), dz. cyt., s. 37-42; A. Lemańska, Praktyczna filozofia przyrody alternatywa klasycznej filozofii przyrody, „Studia Philosophiae Chistianae" 1 (1997), s. 133-138; Z. Łepko, Antropologia kryzysu ekologicznego, Warszawa 2003.

15 Por. J. M. Dołęga, W kierunku ekofilozofii, w: W. Tyburski (red.), Ekofilozofia, s. $19-25$. 
gdzie już wyróżnia się filozofię przyrody nieożywionej (kosmofilozofię) i filozofię przyrody ożywionej (biofilozofię) oraz filozofię środowiska społeczno-przyrodniczego (ekofilozofię).

12. Ekofilozofia jako kulturalistyczna filozofia ekologii reprezentowana w Polsce przez Andrzeja Papuzińskiego ${ }^{16}$.

13. Ekofilozofia jako enwironmentalizm ${ }^{17}$ - proponowana przez Wiesława Sztumskiego z Instytutu Filozofii Uniwersytetu Śląskiego w Katowicach.

14. Ekofilozofia jako samodzielna nauka filozoficzna ${ }^{18}$ - o wyraźnie określonym statucie epistemologicznym i metodologicznym.

15. Ekofilozofia jako światopogląd o aspektach etycznych, prawnych i moralnych ${ }^{19}$, szukająca również podstaw w ekoteologii.

16. Ekofilozofia jako filozofia zrównoważonego rozwoju ${ }^{20}$.

17. Ekofilozofia jako filozofia bezpieczeństwa ekologicznego i społecznego ${ }^{21}$.

18. Biocentryczna koncepcja ekofilozofii w ujęciu Zdzisławy Piątek ${ }^{22}$ z Uniwersytetu Jagiellońskiego. Do zagadnień ważnych w ekofilozofii Pani Profesor zalicza następujące: pojęcie i przedmiot ekofilozofii; etyka szacunku dla życia Alberta Schweitzera a ekofilozofia; projekt etyki naukowej

${ }^{16}$ Por. A. Papuziński, Życie-nauka-ekologia. Prolegomena do kulturalistycznej filozofii ekologii, Bydgoszcz 1998.

17 Por. W. Sztumski, Enwironmentalizm i cywilizacja życia, Katowice 1997; tenże, Enwironmentalizm i edukacja proekologiczna, w: J. M. Dołęga, J. W. Czartoszewski, A. Skowroński (red.), dz. cyt.; tenże, My zagubieni w świecie. Przyczynek do filozofii środowiska jako podstawy enwironmnetologii, Katowice 2003.

${ }_{18}$ Por. J. M. Dołęga, Z zagadnień metateoretycznych i merytorycznych, „Studia Philosophiae Christianae" 1 (1996), s. 270-278; tenże, Ekologia w teologii i filozofii chrześcijańskiej, w: A. Papuziński (red.), Wprowadzenie, s. 133-163; tenże, Problematyka ochrony środowiska społeczno-przyrodniczego w sozologii i ekofilozofii, w: J. M. Dołęga, J. W. Czartoszewski, A. Skowroński (red.), dz. cyt., s. 10-26.

19 Por. J. W. Czartoszewski, Zagadnienie światopogladu w edukacji ekologicznej, „Studia Ecologiae et Bioethicae" 1 (2003), s. 505-518; J. M. Dołęga, J. W. Czartoszewski, A. Skowroński (red.), dz. cyt.; J. M. Dołęga, J. W. Czartoszewski (red.), Ochrona środowiska w filozofii i teologii, Warszawa 1999.

${ }^{20}$ Por. A. Pawłowski, Rozwój zrównoważony - idea, filozofia, praktyka, Lublin 2008; A. Skowroński, Filozofia zrównoważonego rozwoju w ujęciu Stefana Kozłowskiego, Warszawa 2002; tenże, Ekofilozoficzny wymiar koncepcji zrównoważonego rozwoju, w: A. Pawłowski (red.), Filozoficzne i społeczne uwarunkowania zrównoważonego rozwoju, t. 16, Lublin 2003.

${ }^{21}$ Por. przykładowo następujące prace: C. Starczewski (red.), Konflikt ekologiczny, Warszawa 2007; M. Pietraś, Bezpieczeństwo ekologiczne w Europie. Studium politologiczne, Lublin 2000.

${ }^{22}$ Z. Piątek, Ekofilozofia, Kraków 2008. 
Kazimierza Twardowskiego a współczesne etyki ewolucjonistyczne; naukowy i filozoficzny kontekst ekofilozofii; czy istnieje nieuchronny antagonizm między naturą a kulturą?; idea zrównoważonego rozwoju w kontekście ekofilozofii.

19. Edukacyjno-dydaktyczna koncepcja ekofilozofii w ujęciu Stefana Konstańczaka ${ }^{23}$, który do głównych zagadnień zalicza następujące problemy: człowiek i przyroda, filozoficzne źródła refleksji nad ochroną środowiska, ekofilozofia jako subdyscyplina filozofii, koncepcje ekofilozofii, wizje społeczeństwa ekologicznego, fenomen życia.

\subsection{Podstawowa problematyka merytoryczna ekofilozofii}

W powstających naukach podstawowym zagadnieniem jest wypracowanie statusu epistemologicznego i metodologicznego oraz struktury zagadnień merytorycznych, stanowiących pewną zwartą logiczną całość. W tym miejscu pomijamy szczegółowe analizy zagadnień metateoretycznych, a jedynie zwróci się uwagę Czytelnika na przedmiot badań ekofilozofii.

Każda nauka ma swoją prehistorię. Podobnie i ekofilozofia ma już swoją prehistorię, a mianowicie wszyscy uczeni zajmujący się zagrożeniami i ochroną środowiska społeczno-przyrodniczego, a zwłaszcza autorzy przytoczonych powyżej koncepcji tej nauki, są prekursorami ekofilozofii. Biorąc pod uwagę aktualny stan badań naukowych z zakresu ekofilozofii, nie sposób dzisiaj określić definitywnie przedmiotu badań tej nauki. Jednak na podstawie istniejącej literatury i toczących się dyskusji na różnych sympozjach i konferencjach naukowych można przyjąć robocze określenia przedmiotu ekofilozofii: przedmiotem badań ekofilozofii jest istota i natura środowiska społeczno-przyrodniczego, jego właściwości ilościowe i jakościowe oraz dwustronne związki przyczynowe między antroposferą a środowiskiem; a może krócej: przedmiotem badań ekofilozofii jest istota i natura ekosystemu ziemskiego i jego otoczenia (lub ekosystemów i ich otoczenia).

W nurcie określonego myślenia filozoficznego poznanie z zakresu ekofilozofii zmierzałoby do poznania środowiska realnie i faktycznie istniejącego; do poznania w aspektach koniecznościowych i przyczynowych, a nie tylko przygodnych; do uzyskiwania uzasadnień tez ekofilozoficznych racjami logicznymi, ontycznymi, realnymi i przyczynowymi ${ }^{24}$. Inaczej mówiąc:

${ }^{23}$ S. Konstańczak, Wybrane zagadnienia ekofilozofii, Słupsk 2005.

${ }^{24}$ Por. K. Kłósak, Z teorii i metodologii filozofii przyrody, Poznań 1980, s. 46-49, 105, 113; J. M. Dołęga, Stosunek ruchu do materii w ujęciu klasycznej filozofii przyrody, Warszawa 1986, s. 29-30. 
ekofilozofia jest nauką o systemowym ujęciu problematyki filozoficznej środowiska społeczno-przyrodniczego.

Zasadniczym źródłem informacji o środowisku są różne nauki szczegółowe, a szczególnie ekologia i sozologia. Wydobycie problematyki filozoficznej z naukowego obrazu środowiska społeczno-przyrodniczego i kulturowego należy między innymi do zadań ekofilozofii.

Z zagadnień merytorycznych ekofilozofii wymieniamy tylko te, które stanowią zasadniczą strukturę przedmiotową tej nauki. Do niej należy problematyka ogólnofilozoficzna, antropologiczna, aksjologiczna i edukacyjna, dotycząca środowiska społeczno-przyrodniczego łącznie ze środowiskiem kulturowym.

Ogólnofilozoficzna problematyka ekofilozofii ${ }^{25}$ dotyczy istoty i natury środowiska społeczno-przyrodniczego, jego właściwości ilościowych i jakościowych, zmian zachodzących w tych właściwościach oraz związków przyczynowych między antroposferą a biosferą. Chodzi tutaj przede wszystkim o zdanie sprawy z aktualnego stanu środowiska, źródeł zmian zachodzących w tym środowisku, jego wpływu na życie i zdrowie człowieka, jak również szukanie podstaw filozoficznych ochrony tego środowiska. Podstawą do prowadzenia badań w tym zakresie są dane z przyrodniczych nauk szczegółowych i antropologicznych. Podejmowana problematyka ogólnofilozoficzna w ekofilozofii i próby jej rozwiązania są oparte w sensie metodologicznym o tak zwany naukowy obraz świata, w tym przypadku chodzi przede wszystkim o naukowy obraz środowiska społeczno-przyrodniczego.

Antropologiczna problematyka ekofilozofii ${ }^{26}$ dotyczy przede wszystkim zagadnień filozoficznych związanych z demografią, ontogenezą, antropopresją, migracją oraz ze strukturalnymi elementami antroposfery, do których zalicza się przede wszystkim naukę, technikę i technologię, sztukę i religię. Punktem wyjścia do tego rodzaju badań są dane z antropologii przyrodniczej, filozoficznej, społecznej i kulturowej oraz z ekologii człowieka, sozotechniki, religiologii, filozofii i historii nauki, historii i filozofii kultury. Podejmowana filozoficzna problematyka antropologiczna w ekofilozofii oraz sposoby jej rozwiązywania zależą od przyjmowanych przez autorów systemów filozoficznych założeń.

${ }_{25}$ Por. S. Zięba, Życie w aspekcie ekologicznym, „Człowiek i przyroda” 2 (1995), s. 5-21; J. Dębowski, Filozoficzne źródła refleksji ekofilozoficznych, Olsztyn 1996.

${ }^{26}$ Por. N. Wolański, Rozwój biologiczny człowieka, cz. 1 i 2, Warszawa 1986; S. Kowalczyk, Zarys filozofii człowieka, Sandomierz 1990; M. Wójcik (red.), Człowiek-osoba-płeć, Warszawa 1998; N. Wolański, Rozwój biologiczny człowieka, Warszawa 2005. 
Aksjologiczna problematyka ekofilozofii ${ }^{27}$ występuje przy wartościowaniu życia, zdrowia człowieka, środowiska. Podstawy wartościowania wypracowywane są w aksjologii związanej z filozofią bytu i antropologią. W ramach naszej koncepcji ekofilozofii życie oraz życie i zdrowie człowieka ujmujemy jako wartości najwyższe, ale nie absolutne. Natomiast środowisko społeczno-przyrodnicze traktuje się jako wartość podstawową i dobro wspólne. Wypracowane tutaj wartości mogą stać się podstawą wypracowania etyki ogólnej oraz etyki środowiskowej, a nawet prawodawstwa ekologicznego i moralności. Wydaje się, że wiedza naukowa związana ze środowiskiem społeczno-przyrodniczym oraz wypracowana i akceptowana etyka środowiskowa mogą stać się podstawą dla ekorozwoju.

Edukacyjna problematyka ekofilozofii ${ }^{28}$ dotyczy przede wszystkim podstaw filozoficznych wychowania proekologicznego, a ściślej mówiąc wychowania sozologicznego w rodzinie, w szkole, w massmediach, w organizacjach społecznych, religiach oraz w ogólnej edukacji narodowej. Kształtowanie świadomości wrażliwej na wartość środowiska społeczno-przyrodniczego zależy również od programów nauczania w przedszkolach, szkołach podstawowych, średnich i na uczelniach wyższych oraz od powszechnej edukacji ekologicznej dorosłych. Ponadto jest to zadanie dla wszystkich zdających sobie sprawę z jakości aktualnego środowiska i jego wpływu na życie na naszej planecie oraz z jego wpływu na życie i zdrowie człowieka w naszej Ojczyźnie, jak i na całym świecie. Jest to zadanie nie tylko dla filozofów jak pisze M. Barnier ${ }^{29}$ - ale dla wszystkich mających wpływ na świadomość społeczną w Polsce i w świecie.

${ }^{27}$ Por. K. Kloskowski, O naczelnej zasadzie etycznej relacji: człowiek - środowisko, w: J. Dębowski (red.), dz. cyt., s. 107-112; W. Tyburski, Etyka środowiskowa a paradygmat antropocentryzmu, w: W. Tyburski (red.), Ekofilozofia, s. 65-72; Z. Piątek, Dylematy etyki środowiskowej, w: W. Tyburski (red.), Ekofilozofia, s. 43-64. Ponadto por. 16 artykułów w pracy zbiorowej na temat: W. Tyburski (red.), Ekonomia - ekologia - etyka, Toruń 1996; J. Łukomski, Próba zbudowania chrześcijańskiej etyki środowiska naturalnego, Radom 1998.

${ }^{28}$ Por. M. R. Dudzińska, L. Pawłowski (red.), Materiały II Ogólnopolskiej Konferencji Ochrona środowiska w nauczaniu i wychowaniu, Lublin 1993; C. Napiórkowski, W. Koc (red.), Chronić by przetrwać, Niepokalanów 1992; K. Dubel (red.), Edukacja ekologiczna wobec współczesności i wyzwań przyszłości, „Przyroda i Człowiek” - zeszyt specjalny, Opole-Pokrzywna 1995; D. Cichy (red.), Edukacja środowiskowa. Agenda 21 - realizacja zadań edukacyjnych, Warszawa 1997; Problemy dydaktyki i wychowania w Akademii Rolniczej w Poznaniu, 14: Edukacja i świadomość ekologiczna, Poznań 1997; I. Fudali, Ekologiczne wyzwania regionalnych programów edukacji środowiskowej, Kielce 1997; J. Frątczak, Świadomość ekologiczna dzieci, młodzieży i dorosłych w aspekcie edukacji szkolnej i nieszkolnej, Bydgoszcz 1995; J. M. Dołęga, Znaczenie sozologii i ekofilozofii w systemie edukacji ekologicznej, w: J. L. Krakowiak, J. M. Dołęga (red.), Hipoteza ekologii ekologicznej, Warszawa 1999, s. 53-65; „Edukacja Biologiczna i Środowiskowa” 2-3 (2004).

${ }_{29}$ M. Barnier, Atlas wielkich zagrożeń, Warszawa 1995, s. 9. 


\section{Sozologia}

\subsection{Koncepcja sozologii systemowej}

Z systemowej koncepcji sozologii wynika systemowe ujęcie zagadnień metateoretycznych i merytorycznych tej nauki. Określając przedmiot badań, a zwłaszcza wskazując na jego interdyscyplinarny charakter oraz systemowy wymóg stawiany wobec metod stosowanych $\mathrm{w}$ tej nauce, $\mathrm{z}$ dużym prawdopodobieństwem można twierdzić, że teoretyczne i praktyczne działania sozologiczne będą wtedy skuteczne, gdy obejmą następujące obszary badawcze:

- antroposferę,

- biosferę,

- atmosferę,

- hydrosferę,

- litosferę,

- kosmosferę.

Wszystkie te obszary tworzą dość złożone systemy, nie mówiąc o swoistej całości, w której rozwija się życie i człowiek.

W systemowej koncepcji sozologii chodzi o ujęcie w jedną całość wszystkich tych obszarów. Całość tę przyjęło się nazywać systemem wiel$\mathrm{kim}^{30}$. Termin ten jest pomocny w opisie nie tylko różnorakich podsystemów przyrodniczych, ale również w opisie podsystemów społecznych, ekonomicznych, technicznych, przemysłowych itp. Wielki system to jeden wielki obiekt sterowania.

Wielki system - według M. Lubańskiego ${ }^{31}$ - charakteryzuje się następującymi właściwościami:

- system ten składa się z podsystemów, które można wyróżnić i opisać;

- każdy z podsystemów ma własny cel działania, a jego efektywność może być oceniana w zależności od procesu sterowania;

- cały system ma ogólny cel działania, a jego efektywność ocenia się na podstawie działania podsystemów;

- w podsystemach, jak też między nimi, zachodzą liczne sprzężenia;

- w systemie istnieje hierarchiczna struktura sterowania;

- rozbudowana sieć informacyjna gwarantuje celowe funkcjonowanie i optymalizację systemu;

${ }^{30}$ Por. Z. Kierkowski, dz. cyt., s. 498; A. A. Lapunów, Systemy biologiczne jako systemy wielkie, w: Problemy metodologii, s. 149-180.

${ }^{31}$ M. Lubański, Informacja, s. 29-31; Z. Kierzkowski, dz. cyt., s. 497-498. 
- w systemie obserwuje się współdziałanie ludzi, maszyn i środowiska przyrodniczego - wszystkie te elementy systemu tworzą środowisko, które (w następstwie) na nie oddziałuje.

Wymienione cechy wielkiego systemu należy uwzględnić w sozologii jako teoretycznej nauce dotyczącej antroposfery, biosfery, atmosfery, hydrosfery i kosmosfery oraz nauk praktycznych związanych z tą nauką, które rejestrują zagrożenia życia i zdrowia człowieka, starają się im zapobiec i je usunąć. Do takich nauk należy zaliczyć na przykład sozotechnikę, sozoekonomię, prawo ekologiczne, sozopsychologię, filozofię medycyny.

W systemowej koncepcji sozologii bierze się pod uwagę wiele podsystemów, które mają własne cele działania, ale efektywność ich i ocena tej efektywności zależy od procesu sterowania. Cały wielki system, nazwijmy go technicznie „sozologiczny”, ma ogólny cel działania, którego efektywność zależy od działania podsystemów. Celem tym jest utrzymanie na Ziemi optymalnych warunków życia oraz warunków rozwoju i zdrowia człowieka. Czymś oczywistym jest, że między podsystemami i w nich samych zachodzą liczne sprzężenia. Efektywność takiego systemowego stawiania i rozwiązywania problematyki sozologicznej zależy natomiast od hierarchicznej struktury sterowania oraz od dobrze rozbudowanej sieci informacyjnej.

Systemowa koncepcja sozologii występuje w sozologicznych badaniach metateoretycznych i merytorycznych. Wydaje się, że jest ona wystarczająco uzasadniona, a ponadto syntetyzuje empiryczną, humanistyczną i filozoficzną koncepcję tej nauki i jest w stanie w sposób zadowalający rozwiązywać problematykę sozologiczną.

\subsection{Epistemologia sozologii systemowej}

Przez epistemologię rozumiemy teorię poznania naukowego, zajmującą się poznaniem naukowym w aspekcie jego treści, w odróżnieniu od aspektu formalnego poznania naukowego, którym zajmuje się logika, metodologia i metodyka lub technologia nauki. Tak rozumiana epistemologia polega na zastosowaniu zasad teorii poznania naukowego i na analizowaniu problemów teoriopoznawczych napotykanych w pracy naukowej.

Do zagadnień epistemologicznych sozologii zaliczamy przede wszystkim analizę pojęcia tej nauki, konstrukcję jej definicji, określenie przedmiotu jej badań oraz zaakcentowanie charakterystycznej cechy sozologicznych badań naukowych, a mianowicie ich intedyscyplinarności. Zagadnienia te może nie stanowią wyczerpującego zbioru epistemologicznych problemów sozologii systemowej, ale są istotnymi elementami aspektu struktury poznania naukowego właściwego tej nauce. 
Pojęcie. Termin „sozologia” pochodzi od greckiego słowa $\sigma \omega \zeta \omega$ - (sodzo), które znaczy „ochraniać”, „ocalać”, „zachowywać”, „ratować”, „pomagać". Termin ten do polskiego słownika naukowego wprowadził W. Goetel na początku lat sześćdziesiątych XX wieku. Według niego, termin ten oznacza naukę o ochronie przyrody, o ochronie naturalnego środowiska człowieka. Od tego czasu upłynęło ponad trzydzieści lat. Termin „sozologia” został wzbogacony nowymi treściami i tym samym poszerzono jego zakres. Wyrazem tego jest bogata literatura przedmiotowa ${ }^{32}$. Terminu tego używa się też na określenie nauki o ochronie środowiska.

W analizie pojęcia „sozologia” uwzględniamy dwa aspekty: treściowy i zakresowy. W aspekcie treściowym wskażemy na elementy metodologiczne i przedmiotowe tego pojęcia, natomiast $\mathrm{w}$ aspekcie zakresowym - elementy wyznaczające jego zakres.

$\mathrm{W}$ aspekcie metodologicznym ${ }^{33}$ treści pojęcia „sozologia” mówi się przede wszystkim o metodach służących do badań przedmiotu tej nauki. Wyróżnia się tutaj metody empiryczne, humanistyczne, filozoficzne i systemowe.

W aspekcie przedmiotowym ${ }^{34}$, dotyczącym treści pojęcia „sozologia”, należy wyszczególnić zagadnienia i problemy wchodzące w zakres nauko-

32 A. Wodziczko, Kierunki współczesnej ochrony przyrody, „Przyroda i Technik” 4 (1935), s. 145-147; tenże, Ochrona przyrody jako nauka i jej potrzeby, „Chrońmy Przyrodę Ojczystą” 1 (1946), s. 8-15; W. Goetel, Sozologia - nauka o ochronie przyrody i jej zasobów, „Kosmos A” 1 (1972), s. 31-38; W. Michajłow, Sozologia a problemy środowiska życia człowieka, Warszawa 1975; J. M. Dołęga, Z zagadnień sozologii, „Z Zagadnień Filozofii Przyrodoznawstwa i Filozofii Przyrody" 4 (1982), s. 328-327; A. Zdrójkowska (red.), Człowiek i przyroda, Warszawa 1986; Z. Wójcik, By ziemia pozostała piękna i zasobna, Warszawa 1986, s. 20-36; J. Eil-Eibesfeldt, Galapagos. Arka Noego pośród Pacyfiku, Katowice 1988, s. 255-263; J. M. Dołęga, Zarys sozologii systemowej, Warszawa 2005.

${ }^{33}$ Por. J. I. Marczuk, Modelowanie matematyczne problemów środowiska naturalnego, Warszawa 1985; B. Głowiak, Modele obliczeniowe, w: B. Głowiak, E. Kempa, T. Winnicki, Podstawy ochrony środowiska, Warszawa 1985, s. 104-126; J. Juda, Zasady stosowania analizy w ksztaltowaniu środowiska, w: W. Michałow i in. (red.), Człowiek i Środowisko, cz. 1, Wrocław 1978, s. 151-180; E. Tomaszewski, Rola obserwacji satelitarnych w ochronie i ksztattowaniu środowiska, w: W. Michałow i in. (red.), dz. cyt., cz. 2, Wrocław 1979, s. 161-188; B. Głowiak, Krązenie zanieczyszczeń w biosferze i metody tzw. monitoringu, w: W. Michałow i in. (red.), dz. cyt., cz. 2, s. 189-224.

${ }^{34}$ Por. K. Jacniacki, Środowisko przyrodnicze i jego ochrona, Warszawa 1989; J. J. Skoczylas, Cywilnoprawne środki ochrony środowiska, Warszawa 1986; A. Leńkowa (red.), Człowiek przeciwko sobie, Warszawa 1986; Z. Stromenger, Przystosowani pożyja dlużej, Katowice 1988; G. Fleming, Klimat -środowisko - człowiek, Warszawa 1983; C. W. Korczak, Higiena ochrona zdrowia, Warszawa 1984; A. Ginsbert-Gebert (red.), Ekonomiczne i socjologiczne problemy ochrony środowiska, Wrocław 1991; B. Fiedor, Przyczynek do ekonomicznej teorii zanieczyszczenia i ochrony środowiska, Wrocław 1990; A. Biela (red.), Stres psychiczny w sytuacji kryzysu ekologicznego. Badania z zakresu sozopsychologii, Lublin 1984; N. Wolański, 
wych badań sozologicznych. Przykładowo można tutaj wymienić takie problemy i zagadnienia jak:

- opis faktyczny stanu przyrody w świecie i w Polsce;

- określenie obiektów, które zanieczyszczają i niszczą środowisko naturalne człowieka;

- przeprowadzenie badań technicznych i technologicznych w celu wprowadzenia urządzeń oczyszczających i technologii nieuciążliwych dla naturalnego środowiska człowieka;

- badanie wpływu zmienionego środowiska na organizmy żywe i na człowieka;

- tworzenie zabezpieczeń prawnych i administracyjnych w skali międzynarodowej i krajowej w celu realizacji programów ochrony naturalnego środowiska człowieka;

- budzenie świadomości moralnej i etycznej wrażliwej na jakość naturalnego środowiska człowieka;

- wychowanie - na różnych szczeblach edukacji narodowej-w duchu wrażliwości na wartość naturalnego środowiska człowieka;

- szukanie środków zmniejszających zanieczyszczenie naturalnego środowiska człowieka i eliminowanie źródeł jego zanieczyszczeń;

- badanie wpływu środowiska naturalnego na stan psychiczny człowieka;

- prowadzenie medycznych badań nowych jednostek chorobowych, powstałych pod wpływem zmienionego środowiska;

- zabezpieczenie „czystych” rezerw genetycznych.

Powyższy wykaz zagadnień i problemów nie jest kompletny, ale w sposób wystarczający ilustruje bogatą i zróżnicowaną treść pojęcia sozologii.

Aspekt zakresowy pojęcia sozologii ${ }^{35}$ obejmuje problemy i zagadnienia dotyczące przyrody nieożywionej i ożywionej oraz antroposfery. Wszystkie te obszary rozpatrywane są w aspekcie ochrony naturalnych właściwości poszczególnych obiektów przyrodniczych i ich wpływu na życie i zdrowie człowieka. W aspekcie tym, który jest charakterystyczny dla sozologii, mieszczą się badania naturalnych właściwości obiektów nieożywionych i ożywionych oraz ich właściwości powstałych pod wpływem działalności

Populacja ludzka jako bioinduktor stanu środowiska (środowiskowe uwarunkowania rozwoju biologicznego ludności Polski), „Nauka Polska” 1 (1989), s. 31-56.

${ }_{35}$ Por. J. Gręczewski, Wpływ pogody na zdrowie człowieka, Warszawa 1972; S. Tyszka, J. Ponikowska, Człowiek, pogoda, klimat, Warszawa 1983; N. W. Skinder, Chemia a ochrona środowiska, Warszawa 1991; S. Kozłowski, Ochrona środowiska, w: J. Kopczyński, A. Siciński (red.), Człowiek, środowisko, zdrowie, Wrocław 1990, s. 377-383; M. Nikonorow, Główne skażenia ekologiczne żywności, w: J. Kopczyński, A. Siciński (red.), dz. cyt., s. 321-332; J. Sommer, System prawa a problemy środowiska i zdrowia, w: J. Kopczyński, A. Siciński (red.), dz. cyt., s. 365-376. 
człowieka. Badania te dotyczą również nowo powstałych właściwości środowiska naturalnego i ich wpływu na zdrowie i życie człowieka, a także ich wpływu na kondycję innych gatunków żyjących na ziemi.

Definicja. W początkowych stadiach powstawania i rozwoju nieomal każdej nauki występują trudności z jej definiowaniem. Również sozologia nie wyszła jeszcze z początkowej fazy rozwoju. Mimo że problematykę ochrony przyrody podejmowano już w XIX wieku, to jednak nadal boryka się ona z podobnymi trudnościami.

$\mathrm{Z}$ zastanych definicji sozologii wybieramy dwie, podane przez W. Michajłowa:

D1 Sozologia, nauka o ochronie przyrody, zajmuje się przyczynami, doraźnymi skutkami oraz dalszymi następstwami przemian zachodzących w wyniku działalności gospodarczej i społecznej człowieka zarówno w naturalnych, jak i uprzednio odkształconych układach przyrodniczych na mniejszym lub większym obszarze biosfery. Zakresem swym obejmuje skuteczne sposoby zapobiegania ujemnym dla społeczeństw następstwom działalności człowieka w środowisku naturalnym bądź przynajmniej wskazuje możliwości maksymalnego ich złagodzenia ${ }^{36}$.

D2 Sozologia jest nauką o przyczynach i doraźnych skutkach, a także dalszych następstwach przemian zachodzących zarówno w naturalnych, jak i uprzednio już odkształconych układach przyrodniczych na mniejszym lub większym obszarze biosfery w wyniku działalności społecznej i gospodarczej człowieka oraz skutecznych sposobach zapobiegania jej ujemnym następstwom dla społeczeństw lub przynajmniej o możliwościach maksymalnego ich złagodzenia ${ }^{37}$.

Podane powyżej definicje sozologii są bardzo rozbudowane i w sposób szczegółowy określają przedmiot, zadania i zakres badań tej nauki. Określenia te sugerują, że sozologia ma charakter interdyscyplinarny, co determinuje wybór i konstruowanie metod badawczych stosowanych w tej nauce. W definicjach tych nie zwraca się jednak uwagi na potrzebę ujęć całościowych w badaniach sozologicznych.

W niniejszej pracy proponujemy następującą definicję sozologii:

D3: Sozologia jest nauką o systemowej ochronie środowiska przed destrukcyjnym oddziaływaniem antroposfery.

${ }^{36}$ W. Michajłow, Sozologia - nauka o ochronie i ksztaltowaniu środowiska, w: T. Kotarbiński, W. Osińska, E. Geblewicz (red.), Nowe specjalności w nauce wspótczesnej, Wrocław 1997, s. 159.

${ }^{37}$ Tamże, s. 50. 
Wyjaśnień wymagają następujące, użyte w definicji, wyrażenia: „systemowa ochrona”, „,biosfera”, ,,antroposfera”, „destrukcyjne działanie”.

„Systemowa ochrona” - wyrażenie to wiąże się z systemowym podejściem do badań naukowych, które charakteryzują się całościowym ujęciem problematyki i zarazem wskazują na sprzężenia zwrotne zachodzące między elementami wewnątrzsystemowymi i między systemem a jego otoczeniem. Przez system - jak pisaliśmy wcześniej - rozumiemy zespół różnych elementów wzajemnie ze sobą powiązanych, na siebie oddziałujących i stanowiących pod pewnym względem całość. Określenie to nawiązuje do filologicznego znaczenia terminu ,system” (gr. systema) i podkreśla taki układ elementów, który tworzy pewną całość uwarunkowaną stałym ładem jego części składowych w świecie realnym lub w sferze poznania ludzkiego. System stanowi całość, w której elementy są powiązane z sobą relacjami oddziaływania i stanowią jego strukturę. Każdy system otwarty ma swoje otoczenie. W przyrodzie i w poznaniu ludzkim występują przede wszystkim systemy otwarte. Otoczenie jest to rzeczywistość, która wchodzi lub może wchodzić w relacje z systemem. Zatem ,systemowa ochrona” biosfery oznacza całościowe i wszechstronne działanie człowieka na rzecz ochrony przyrody w sferze nauki, techniki, technologii, pedagogiki i dydaktyki.

Termin „,biosfera"38 oznacza przestrzeń zamieszkaną przez organizmy żywe. Przestrzeń ta obejmuje następujące obszary:

- powierzchnię ziemi i jej górną warstwę, około 2-3 km w głąb litosfery (głębiej w skorupie ziemskiej spotyka się tylko bakterie);

- dolną część atmosfery, do wysokości kilkuset metrów (wyżej unoszą się w atmosferze bakterie, zarodniki i bardzo małe owady);

- całą hydrosferę, czyli wszystkie wody na kuli ziemskiej.

Termin „,antroposfera” oznacza całą przestrzeń różnorakiej działalności człowieka, a więc gospodarczej, społecznej, kulturalnej, politycznej, naukowej, twórczej i wytwórczej.

Wyrażenie „destrukcyjne oddziaływanie” oznacza całą działalność człowieka, która wchodzi w konflikt z biosferą, która zmienia naturalne środowisko życia oraz powoduje strukturalne zmiany genetyczne niektórych roślin i zwierząt, w tym również człowieka; ma ona również wpływ na chemiczną i biologiczną równowagę w biosferze.

Przedmiot. Przedmiotem badań sozologii w sensie ogólnym jest wzajemne oddziaływanie biosfery i antroposfery. W języku tradycyjnym jest to materialny przedmiot tej nauki. Formalnym zaś przedmiotem badań sozologii

${ }^{38}$ Por. Biosfera i jej zasoby, Warszawa 1976; E. Geissler, E. Libbert, J. Nitschmann, G. Thomas-Petersein (HRSG.), Kleine Enzyklopadie. Leben, Leipzig 1978, s. 13; A. Witkowska (red.), Biosfera, Warszawa 1973. 
jest ochrona biosfery przed destrukcyjnym działaniem na nią antroposfery. Ten aspekt ochrony czy osłony stanowi o specyfice sozologii i jej odrębności od innych nauk o biosferze $\mathrm{i}$ antroposferze, $\mathrm{tj}$. o ekosystemie ziemskim.

Zakres badań sozologii obejmuje - przy takim scharakteryzowaniu jej przedmiotu - przyrodę nieożywioną i ożywioną, przez którą rozumie się kosmo-bio-geograficzne środowisko życia, ulegające pod wpływem oddziaływania antroposfery wielorakim zmianom, a czasem całkowitej destrukcji.

W zakres tak pojmowanego przedmiotu badań sozologii wchodzą rośliny i zwierzęta, ich struktury genetyczne i prawidłowy rozwój, a także zakłócenia rozwojowe spowodowane działaniem antroposfery. Do zakresu badań sozologicznych należy też środowisko fizyczne, w którym tkwi biosfera, a mianowicie atmosfera, hydrosfera, litosfera i kosmosfera.

Po tym ogólnym omówieniu przedmiotu badań sozologii należy wyszczególnić zagadnienia podejmowane $\mathrm{w}$ ramach sozologicznych badań naukowych. Zagadnienia te mieszczą się w zakresie badań sozologii oraz dotyczą biosfery i antroposfery, a także zachodzących między nimi relacji.

Wśród zagadnień dotyczących biosfery należy wymienić problemy natury biologicznej i biologiczno-genetycznej. Zadania związane z tą problematyką sprowadzają się do opisu aktualnego stanu biosfery uwzględniającego jej środowiska: atmosferyczne, wodne, geologiczne, a nawet kosmiczne.

Do zagadnień sozologicznych, związanych ze zjawiskami antroposfery, należą problemy dotyczące stanu biologicznego i biologiczno-medycznego populacji ludzkich w poszczególnych krajach i na całych kontynentach oraz problematyka, która wyłania się wraz z rozwojem sozotechniki ${ }^{39}$, sozopsychologii ${ }^{40}$, sozoekonomii ${ }^{41}$, prawa ekologicznego ${ }^{42}$, etyki ekologicznej ${ }^{43}$.

39 Por. W. Goedel (red.), Sozologia i sozotechnika, „Zeszyty Naukowe AGH” 21 (1971), zeszyt specjalny; B. Głowiak, J. Pecyna, Technologia oczyszczania gazów odlotowych, w: B. Głowiak, E. Kempa, T. Winnicki, dz. cyt., s. 129-156.

${ }^{40}$ Por. A. Biela (red.), dz. cyt..

${ }^{41}$ Por. K. Leszczyński, Rachunek społeczno-ekonomiczny w ochronie środowiska naturalnego, w: W. Michajłow i in. (red.), dz. cyt., cz. 1, s. 95-116; T. Winnicki, Ekonomiczne problemy ochrony środowiska, w: B. Głowiak, E. Kempa, T. Winnicki, dz. cyt., s. 323-336; K. Zabierowski, Ekonomiczne podstawy ochrony przyrody, w: W. Szafer (red.), Ochrona przyrodniczego środowiska człowieka, Warszawa 1973, s. 363-386.

${ }^{42}$ Por. W. Brzeziński, Problematyka prawna ochrony środowiska, w: W. Michajłow i in. (red.), dz. cyt., cz. 1, s. 117-150; J. Sommer (red.), Skuteczność prawa ochrony środowiska $w$ warunkach reformy gospodarczej, Wrocław 1990; tenże (red.), Prawo człowieka do środowiska naturalnego, Wrocław 1987.

${ }^{43}$ Por. T. Ślipko, Granice życia. Dylematy wspótczesnej bioetyki, Warszawa 1988, s. 22-75; J. Aleksandrowicz, Sumienie ekologiczne, Warszawa 1985; F. Woronowski, Ewan- 
W związku z destrukcyjnymi oddziaływaniami antroposfery na biosferę wskazuje się na wielorakie problemy pojawiające się w związku z zagrożeniami:

- fizycznego środowiska biosfery (powietrze, woda, gleba);

- środowiska biologicznego;

- życia i zdrowia człowieka;

- życia w małych, średnich, dużych i wielkich makroregionach;

- poszczególnych populacji, a nawet całych gatunków czy ras, zarówno w faunie, jak i florze;

- krajobrazu, zgrupowań roślin i zwierząt.

Biorąc to wszystko pod uwagę należy jeszcze raz podkreślić, że przedmiotem badań sozologii jest wpływ działalności człowieka na przyrodę oraz metody jej ochrony.

\subsection{Systemowe metody w sozologii systemowej}

We współczesnych teoriach nauki, funkcjonujących w nurcie filozofii tomistycznej, należy wyróżnić systemową teorię nauki, którą formułuje się na podstawie ogólnej teorii systemów i jej zastosowań ${ }^{44}$. Należałoby tu uwzględnić przede wszystkim prace M. Lubańskiego ${ }^{45}$ i S. W. Ślagi ${ }^{46}$ poświęcone teoretycznym ujęciom współczesnej nauki w aspekcie systemowym i zastosowaniom tych ujęć do opisu i rozwiązań konkretnych problemów.

Naukę w stadium apragmatycznym ${ }^{47}$ można określić jako system twierdzeń (zdań) uporządkowanych logicznie, uzasadnionych, intersubiektywnie sprawdzalnych i komunikatywnych. Sformułowanie to wyraża tendencję

gelizacja porządku doczesnego, Łomża 1990, s. 142-159; tenże, Ojczyzna oczekiwana, Łomża 1991, s. 152-154.

${ }_{44}$ Przykładowo wymieńmy następujące pozycje: Problemy metodologii badań systemowych; G. J. Klir (red.), dz. cyt.; L. von Bartalanffy, dz. cyt.; A. Latawiec, Symulacja zjawisk biologicznych widziana systemowo, „Studia Philosophiae Christianae” 2 (1990), s. 37-54.

${ }_{45}$ Por. M. Lubański, Wprowadzenie do informatyki, Warszawa 1979; tenże, Informacja, s. 13-164; tenże, Człowiek, system, informacja, „Studia Philosophiae Christianae” 2 (1978), s. 101-144; tenże, Zagadnienia filozoficzne $w$ aspekcie systemowo-filozoficznym, „Roczniki Filozoficzne" 3 (1981), s. 5-20.

${ }^{46}$ Por. S. W. Ślaga, Ontologia systemowa a filozofia przyrody, „Roczniki Filozoficzne” 3 (1982), s. 119-128; S. W. Ślaga, M. Lubański, Wspólnota kościelna w aspekcie systemowym, w: L. Balter (red.), Człowiek we wspólnocie Kościoła, Warszawa 1979, s. 117-152; S. W. Ślaga, M. Lubański, The System Approach to Scientific Research, „Philosophical Inquiry” 1 (1983), s. 1-13; S. W. Ślaga, U podstaw biosystemogenezy, w: M. Lubański, S. W. Ślaga (red.), W poszukiwaniu prawdy. Pamięci profesora Kazimierza Kłósaka, Warszawa 1987, s. 174-201.

${ }^{47}$ Por. K. Ajdukiewicz, Logika pragmatyczna, Warszawa 1975, s. 177. 
w badaniach z zakresu filozofii nauki, znaną już od czasów Arystotelesa. S. Kamiński wyraża tę myśl w sposób następujący:

Wiedzę teoretyczną nazywa się na ogół poznaniem, które jest pod względem epistemologicznym i metodologicznym zaawansowane tudzież o charakterze wyjaśniającym, choćby w szerokim tego ostatniego terminu sensie. To zaawansowanie wiedzy ma miejsce wtedy, gdy jest ona specjalistyczna (zasadniczo ujmuje swój przedmiot w jednym aspekcie, czyli pod jednym kątem), empirycznie (przynajmniej genetycznie) lub racjonalnie uprawomocniona w sposób kontrolowany, treściowo i logicznie uporządkowana oraz wyrażona w języku informatywnym (intersubiektywnie, czyli jednoznacznie, zrozumiałym przez fachowców $)^{48}$.

W naukowych badaniach systemowych uwzględnia się nie tylko aspekt przedmiotowy i metodologiczny, ale również aspekt społeczny, socjologiczny, wychowawczy, syntetyczny i dynamiczny.

Przypomnijmy z poprzedniego rozdziału pojęcie systemu, a mianowicie że jest on zespołem różnych elementów wzajemnie ze sobą powiązanych oraz na siebie oddziałujących i stanowiących całość pod pewnym względem. W badaniach naukowych z zakresu sozologii wymagane jest podejście systemowe zarówno w aspekcie przedmiotowym, jak i metodologicznym. W badaniach tych wykorzystuje się wiele metod i technik w celu rozpoznania aktualnego stanu biosfery i antroposfery oraz ukazania konieczności zastosowania środków mających zahamować degradację środowiska naturalnego. Zbiór tych wszystkich metod i technik stanowi pewien system możliwości badawczych w sozologii.

Powyższe uwagi o problematyce metodologicznej sozologii ukazują złożoność tej problematyki i postulują potrzebę bardziej analitycznego omówienia wszystkich czterech metod stosowanych w sozologii. Przedstawianie w sposób syntetyczny metod empirycznych, humanistycznych, filozoficznych i systemowych jest zaledwie próbą całościowego ukazania metodologicznej problematyki sozologii, która jest ciągle aktualna i oczekuje na rozstrzygnięcia.

${ }^{48}$ S. Kamiński, Typy wiedzy teoretycznej, „Analecta Cracoviensia” 14 (1982), s. 11-12; por. tenże, O rozwoju teorii empirycznej, „Roczniki Filozoficzne” 3 (1982), s. 129-142; tenże, O kryteriach wartościowania wiedzy teoretycznej, „Roczniki Filozoficzne” 2 (1982), s. 125-130; Z. Hajduk, O akceptacji teorii empirycznej, Lublin 1984. 


\subsection{Główna problematyka sozologii systemowej i jej specyfika}

Główne problemy sozologii systemowej związane są z następującymi zagadnieniami:

- stanem środowiska w Polsce, Unii Europejskiej i świecie;

- źródłami zanieczyszczeń i zagrożeń środowiska przyrodniczego i społecznego;

- wpływem zmieniającego się środowiska na życie na Ziemi oraz na życie i zdrowie człowieka;

- środkami i sposobami ochrony środowiska przyrodniczego i społecznego;

- edukacją środowiskową;

- bezpieczeństwem ekologicznym i społecznym;

- ideą zrównoważonego rozwoju.

Wszystkie te problemy i zagadnienia rozpatrywane są w sozologii systemowej w następujących sferach, w których powstaje i rozwija się życie, a mianowicie:

- atmosferze;

- hydrosferze;

- litosferze;

- kosmosferze i magnetosferze;

- biosferze;

- antroposferze.

Wszystkie te sfery, w których występują różne formy życia, mają swoją strukturę z ustalonymi właściwościami warunkującymi funkcjonowanie tych form życia i również człowieka na Ziemi. W sozologii systemowej rozpatruje się stan tych sfer, zmiany zachodzące w nich, wpływ na życie i zdrowie człowieka oraz szuka się sposobów i środków ochrony wszystkich elementów środowiska.

Mając na względzie założenie jedności nauk, zwłaszcza jedność ich struktury logicznej, stosowanie w nich jednolitego systemu metod logicznych, które stanowią najtrwalszą cechę współczesnej nauki, oraz wpływ jednych badań na drugie i ich wzajemne zależności ${ }^{49}$, staje się jasne, że in-

49 Por. B. Prandecka, Strategia ochrony środowiska-podstawy interdyscyplinarne, w: A. Ginsbert-Gebert (red.), dz. cyt., s. 9-20; F. Russell, M. Garbuny, H. Hooke, Nauka o nauce. Metody objaśniania zjawisk fizycznych, Warszawa 1968, s. 13-30; E. Nagel, Struktura nauki. Zagadnienia logiki wyjaśnień naukowych, Warszawa 1970, s. 7-9; T. Czeżowski, O jedności nauki, w: Fragmenty filozoficzne, seria 3, Warszawa 1967, s. 17-27; tenże, O związku między naukami aksjomatycznymi a naukami empirycznymi, „Studia Pedagogiczne” 18 (1973), s. 11-18; 
terdyscyplinarność jest nieodzowną cechą procesów naukowotwórczych sozologii i zarazem potwierdza suponowaną jedność nauk.

Naukowa problematyka sozologiczna sprawia, że badania interdyscyplinarne są w sozologii rzeczą konieczną. Jej rozwiązywanie wymaga bowiem współpracy z następującymi naukami: ekologią, geologią, ekonomią, naukami technicznymi i technologicznymi, etyką i pedagogiką ${ }^{50}$. Z tej współpracy między kształtującą się nauką, sozologią, a wymienionymi wyżej naukami rodzą się nowe dziedziny naukowe, takie jak sozotechnika, sozoekonomia, sozopsychologia, sozoetyka czy etyka ekologiczna, prawo ekologiczne czy sozologiczne, polityka ekologiczna ${ }^{51}$.

W ogólności można powiedzieć, że problematyka sozologiczna pojawia się w wielu naukach ${ }^{52}$, a jej szczegółowe zagadnienia występują zwłaszcza w takich dyscyplinach jak: nauki medyczne, nauki biologiczne, nauki o ziemi i planowaniu przestrzennym, nauki techniczne, nauki ekonomiczne, nauki prawne i administracyjne, nauki społeczne i humanistyczne. Należy w tym miejscu dodać, że wobec sozologicznej problematyki naukowej nie mogą pozostać obojętne ani kosmofilozofia, ani biofilozofia, ani antropofilozofia, ani ekofilozofia.

Badania z zakresu sozologii, jako nauki o systemowej ochronie biosfery przed destrukcyjnym oddziaływaniem na nią antroposfery, z konieczności domagają się, aby pojawiające się w niej problemy rozwiązywać wyczerpująco i wszechstronnie. Ponadto nauka ta ma charakter unifikujący badania z zakresy wielu dyscyplin naukowych. Na jej terenie mogą powstawać teorie scalające osiągnięcia różnych nauk.

S. Kamiński, Stosunek między poznaniem empirycznym a nieempirycznym w nauce, w: B. Bejze (red.), Z zagadnień kultury chrześcijańskiej, Lublin 1973, s. 253-264.

${ }^{50}$ Por. S. Myczkowski, Ochrona przyrody w szkolnictwie i wychowaniu, w: W. Szafer (red.), dz. cyt., s. 97-106; K. Dubel, Edukacja ekologiczna jako warunek zrównoważonego rozwoju w Polsce, w: III Międzynarodowe Seminarium Ekologiczne. Materiały Konferencyjne, Opole 1991, s. 1-8; I. Jarzyńska, Kształcenie studentów nauczania początkowego w zakresie ochrona środowiska przyrodniczego człowieka, w: III Międzynarodowe, s. 1-12; M. Szyrej, Edukacja środowiskowa prowadzona w Wyższej Szkole Pedagogicznej w Częstochowie, w: III Międzynarodowe, s. 1-14; L. Tomczyńska, Aktywne nauczanie wspótpracy z przyrodapotrzeby, wymagania, możliwości, w: III Międzynarodowe, s. 1-13.

${ }^{51}$ Por. J. Aleksandrowicz, P. Waszczenko, Środowisko w perspektywie medycznej: humanizm ekologiczny szansa przetrwania, w: J. Kopczyński, A. Siciński (red.), dz. cyt., s. 83-92; R. W. Gutt, Problem wzorca lekarza i innych pracowników stużby zdrowia, w: J. Kopczyński, A. Siciński (red.), dz. cyt. s. 468-476; T. Ślipko, dz. cyt., s. 22-70.

${ }^{52}$ Por. J. Stępień (red.), Zadania nauki w dziedzinie racjonalnego ksztaltowania środowiska człowieka, Wrocław 1974, s. 40-88. 


\section{Nauki środowiskowe}

1. Ekologia - termin i definicję tej nauki po raz pierwszy podał Ernest Haeckel w 1866 roku. Rozumienie ekologii w ujęciu E. Haeckla (1834-1919) i uściślone przez S. A. Forbesa (1844-1930) w 1895 roku przetrwało do naszych czasów jak podaje Kazimierz A. Dobrowolski ${ }^{53}$. Ekologia jako nauka biologiczna badająca organizmy flory i fauny w środowiskach biotycznych i abiotycznych jest podstawą kształtującej się w drugiej połowie XX wieku ekologii czlowieka i ekologii społecznej ${ }^{54}$.

2. Ekologia człowieka koncentruje się na badaniu wpływu czynników środowiska społecznego i przyrodniczego na organizm ludzki oraz na badaniu jego możliwości adaptacji do tego środowiska. Ustala się pogląd, że ekologia człowieka staje się dyscypliną o bardzo szerokim przedmiocie badań (por. np. N. Wolański).

3. Ekologia społeczna bada zjawiska z pogranicza socjologii, geografii, demografii i ekologii oraz ekologii człowieka. W ostatnim dziesięcioleciu XX wieku powstaje pilna potrzeba wyodrębnienia dodatkowej dyscypliny naukowej lub rozwiniętego działu w ekologii człowieka, a mianowicie ekologii rodziny ludzkiej.

4. Ekologia rodziny ludzkiej - problematyka ta została podjęta na konferencji międzynarodowej zorganizowanej przez Instytut Filozofii, Centrum Ekologii Człowieka i Bioetyki, Instytut Studiów nad Rodziną w Augustowie w dniach 30-31 maja 2000 roku. Na konferencji tej wypracowano główne pojęcia z zakresu ekologii rodziny ludzkiej oraz wskazano na problemy i zagadnienia dotyczące rodziny ludzkiej. Całość dorobku z tej konferencji opublikowano w trzech tomach serii „Episteme” $(7,8,9)^{55}$.

5. Ecologia humana ${ }^{56}$ (ekologia ludzka) - jest ujęciem problematyki ekologicznej i sozologicznej z uwzględnieniem następujących zagadnień:

53 Por. K. A. Dobrowolski, Polskie nauki ekologiczne wobec wyzwań globalnych i zadań praktycznych w kraju, w: J. L. Krakowiak (red.), Ziemia domem człowieka, Warszawa 1997, s. 5-14.

54 Por. T. Umiński, Ekologia - środowisko - przyroda, Warszawa 1996, s. 12-16; H. Wiśniewski, G. Kowalewski, Ekologia z ochrona i kształtowaniem środowiska, Warszawa 1997, s. 14-18; A. Horst, dz. cyt.; B. Campbell, dz. cyt.; D. Kiełczewski, dz. cyt.; K. Lastowski, Ekologia a filozofia. Od ekologii biologicznej do ekologii jako wiedzy humanistycznej, w: A. Papuziński (red.), Wprowadzenie, s. 11-54.

55 J. W. Czartoszewski, J. M. Dołęga (red.), Ekologia rodziny ludzkiej, „Episteme” 7 (2000); J. W. Czartoszewski, J. M. Dołęga (red.), Rodzina w nauce i kulturze, „Episteme” 8 (2000); J. W. Czartoszewski, J. M. Dołęga (red.), Edukacja ekologiczna w rodzinie, ,Episteme" 9 (2000).

56 Por. S. Jaromi, dz. cyt., s. 34-58. 
odpowiedzi na kryzys ekologiczny, integralnej wizji stworzenia, koncepcji zharmonizowania z przyrodą postępu społeczno-cywilizacyjno-kulturowego, współczesne uaktualnienie filozofii przyrody.

6. Sozologia - nauka ta została scharakteryzowana w drugiej części artykułu.

7. Sozo-ekologia społeczna - taką nazwę proponuje Zbigniew T. Wierzbicki ze środowiska Uniwersytetu Mikołaja Kopernika w Toruniu, wprowadzając zagadnienia ochrony środowiska przyrodniczego i środowiska społecznego w obszary socjologicznych badań naukowych.

8. Sozotechnika ${ }^{57}$ - termin ten oznacza całość badań naukowo-technicznych i technologicznych związanych z ochroną środowiska oraz z wprowadzaniem do produkcji nowych technologii nieniszczących środowiska lub przynajmniej nieuciążliwych dla tego środowiska.

9. Sozoekonomia ${ }^{58}$ - (ekonomia środowiskowa, ekoekonomia) dział ekonomii zajmujący się kosztami produkcji wraz z nakładami na ochronę środowiska, mieści się to $\mathrm{w}$ tak zwanym rachunku sozoekonomicznym przedsiębiorstwa lub jednostki administracyjnej państwa.

10. Etyka środowiskowa ${ }^{59}$ - (inne nazwy, to: etyka ekologiczna, ekoetyka) wyrażenie to w środowiskach naukowych w Polsce zaczyna się utrwalać na oznaczenie nauki zajmującej się zasadami i normami postępowania człowieka wobec środowiska przyrodniczego (biotycznego i abiotycznego) i społecznego. Wyróżnia się w niej kilka orientacji, a mianowicie:

- holistyczną odmianę etyki środowiskowej,

- biocentrycznie zorientowaną etykę środowiskową,

${ }^{57}$ Por. J. Bańka, Zarys filozofii techniki, Katowice 1981; A. Kiepas, Moralne wyzwania nauki i techniki, Katowice-Warszawa 1992; J. Szymański, Technika a eksperymentalne sprawdzanie praw nauki, Poznań 1994; A. Kiepas (red.), Człowiek - technika - środowisko. Człowiek współczesny wobec wyzwań końca wieku, Katowice 1999; Inżynieria procesowa, Warszawa 2000.

${ }^{58}$ Z. Małecki (red.), Problemy sozologiczne aglomeracji miejsko-przemystowych. Wybrane zagadnienia, „Biuletyn” 1 (1993); Z. Małecki (red.), Problemy sozologiczne aglomeracji miejsko-przemysłowych. Huta im. Tadeusza Sendzimira, „Biuletyn” 1 (1994); J. T. Wimpenny, Wartość środowiska. Metody wyceny ekonomicznej, Warszawa 1995; B. Poskrobka (red.), Podejmowanie inwestycji proekologicznych i źródta ich finansowania, Białystok 1995; W. Tyburski (red.), Ekonomia - ekologia - etyka; G. Anderson, J. Śleszyński (red.), Ekonomiczna wycena środowiska przyrodniczego, Białystok 1996.

${ }_{59}$ Por. W. Tyburski, Etyka i ekologia, Torun 1995; Z. Piątek, Etyka środowiskowa. Nowe spojrzenie na miejsce człowieka w przyrodzie, Kraków 1998; W. Tyburski (red.), Etyka środowiskowa. Teoretyczne i praktyczne implikacje, Toruń 1998; A. Pawłowski, Odpowiedzialność za przyrodę, Lublin 1999; J. Łukomski, dz. cyt.; W. Tyburski, Główne kierunki i zasady etyki środowiskowej, w: A. Papuziński (red.), Wprowadzenie, s. 97-132. 
- etykę ochrony zwierząt,

- antropocentryczną odmianę etyki środowiskowej.

Etyka środowiskowa jest w ciągłym rozwoju i pojawiają się coraz to nowe orientacje związane z kierunkami filozoficznymi lub religiami albo z określonym światopoglądem.

11. Bioetyka ${ }^{60}$ - jest określona przez Tadeusza Ślipko jako „dział filozoficznej etyki szczegółowej, która ma ustalić oceny i normy (reguły) moralne ważne w dziedzinie działań (aktów ludzkich) polegających na ingerencji w granicznych sytuacjach związanych z zapoczątkowaniem życia, jego trwaniem i śmiercią”. Problematykę bioetyczną w Instytucie Ekologii i Bioetyki UKSW kontynuuje i rozwija Wojciech Bołoz. W Akademii Podlaskiej badania w tym zakresie prowadzi Józef Jaroń.

12. Prawodawstwo ekologiczne ${ }^{61}$ - pod tym wyrażeniem rozumie się procesy tworzenia prawa ochrony środowiska, jego wdrażania i egzekwowania. Z prawem ochrony środowiska związane jest jego zarządzanie uwarunkowane środkami finansowymi.

13. Ekofilozofia ${ }^{62}$ - została scharakteryzowana w pierwszej części artykułu.

14. Ekoteologia ${ }^{63}$ - postulowana nauka teologiczna zbierająca w całość już opracowane szczegółowe zagadnienia ekologiczne związane z teologią,

${ }^{60}$ Por. T. Ślipko, dz. cyt.; W. Bołoz, Życie w ludzkich rękach-podstawowe zagadnienia bioetyczne, Warszawa 1997.

${ }^{61}$ Por. R. Paczuski, Prawo ochrony środowiska. Stan prawny na dzień 30 czerwca 1994, Bydgoszcz 1994; L. Łukaszuk, Międzynarodowe prawo morza, Warszawa 1997; D. Kiełczewski, Mechanizmy rozwoju prawa ochrony środowiska, Białystok 1998; R. Sobański (red.), Prawa człowieka w państwie ekologicznym, Warszawa 1998; A. Przyborowska-Klimczak (red.), Ekologia i prawo, Lublin 1999; J. Stochlak, Polskie prawo ochrony środowiska, Warszawa 2002.

${ }_{62}$ Z. Hull, Filozofia ekologii, s. 9-29; por. A. Papuziński, Metafizyczne, s. 29-42; Z. Hull, Problemy filozofii, s. 55-96; tenże, O dwóch sposobach, s. 38-45; J. M. Dołęga, Z filozofii, s. 25-37; A. Skowroński (red.), Rozmaitości ekofilozofii, „Episteme” 58 (2006); J. M. Dołęga, Ekofilozofia - nauka XXI wieku, „Problemy Ekorozwoju. Studia filozoficzno-sozologiczne” 1 (2006), s. 17-22.

${ }^{63}$ Por. M. Ozorowski, $W$ kierunku ekoteologii, w: J. M. Dołęga, J. W. Czartoszewski (red.), Ochrona, s. 252-256; S. Urbański, Mistyka ekologii ducha ludzkiego, w: J. M. Dołęga, J. W. Czartoszewski (red.), Ochrona, s. 203-221; J. Bajda, Grzech ekologiczny, w: J. M. Dołęga, J. W. Czartoszewski (red.), Ochrona, s. 222-242; J. W. Czartoszewski, Ekologiczne rachunki sumienia, w: J. M. Dołęga, J. W. Czartoszewski (red.), Ochrona, s. 243-251; M. Ozorowski, Kościól a ekologia, w: J. M. Dołęga, J. W. Czartoszewski (red.), Ochrona, s. 281-283; A. Skowroński, , Kwestia ekologiczna” w nauczaniu Jana Pawła II, w: J. M. Dołęga, J. W. Czartoszewski (red.), Ochrona, s. 284-281; Z. Świerczek, Ekologia-Kościót i Św. Franciszek, Kraków 1990; J. Grzesica, Ochrona środowiska naturalnego człowieka, Katowice 1993; A. L. Szafrański, Chrześcijańskie podstawy ekologii, Lublin 1993; P. Kędzierski, Kościót i ekologia, Rzeszów 1997. 
a mianowicie: grzech ekologiczny, ekologiczny rachunek sumienia, zagadnienie zbawienia świata, moralność ekologiczna, rozwój duchowy człowieka i inne - nauka ta świadczy o dużym zainteresowaniu teologów zagadnieniami ekologicznymi. Praktycznym działaniem w tym zakresie jest program ekologiczny Rady Konferencji Biskupów Europy, w ramach którego organizowane są konferencje naukowe międzynarodowe dotyczące problematyki środowiskowej. W 2003 roku taka konferencja odbyła się we Wrocławiu, w dniach 15-18 maja. Tematem było: Wychowanie do odpowiedzialności za dzieło stworzenia i zrównoważony rozwój.

15. Polityka ekologiczna ${ }^{64}$ - wyrażenie to oznacza badania naukowe, które dotyczą większych przedziałów czasowych i terytorialnych. W badaniach tych należałoby uwzględnić czas przynajmniej kilku pokoleń oraz terytorium, region, kontynent lub całą planetę Ziemię z jej najbliższym otoczeniem kosmicznym. Badania nad świadomością ekologiczną społeczeństwa oraz wdrażanie prawa ekologicznego staje się przedmiotem badań i zainteresowań wielu polityków-naukowców.

16. Psychologia ekologiczna - nowy dział psychologii zajmujący się wpływem środowiska przyrodniczego i społecznego, a w tym miejskiego i wiejskiego, na psychikę człowieka (badania Adama Bieli z KUL-u i Andrzeja Eliasza z WSPS i PAN-u). Problematykę ekopsychologiczną podjęła konferencja międzynarodowa psychologii ekologicznej w dniach 20-22 października 2004 roku w Krakowie w Uniwersytecie Jagiellońskim, gdzie założono pierwsze Stowarzyszenie Ekopsychologii w Polsce.

17. Ekomedycyna ${ }^{65}$ - nowy dział medycyny zajmujący się wpływem zmieniającego się środowiska na zdrowie człowieka, rozpoznaniem nowych jednostek chorobowych i sposobami ich leczenia (Anna Latawiec UKSW).

18. Edukacja środowiskowa ${ }^{66}$ - wyrażenie to, coraz powszechniej używane w szkolnictwie, oznacza to wszystko, co niesie w swojej treści wyrażenie: edukacja ekologiczna i edukacja sozologiczna oraz pewne aspekty samego terminu szeroko rozumianego środowiska. Dlatego edukacja środowiskowa zawiera w swojej treści następujące aspekty: biologiczny, abiotycz-

${ }^{64}$ Por. S. Kozłowski, $W$ drodze do ekorozwoju, Warszawa 1997, s. 187-209; L. Ryszkowski, S. Balazy (red.), Zasady ekopolityki w rozwoju obszarów wiejskich, Poznań 1995; H. Lisicka, Organizacje ekologiczne w polskich systemach politycznych, Wrocław 1997; W. Mirowski, P. Gliński (red.), Świadomość ekologiczna i społeczne ruchy „Zielonych” w Polsce, Warszawa 1999.

${ }^{65}$ Por. J. Wróbel, Człowiek i medycyna, Kraków 1999; S. Kornas, Wspótczesne eksperymenty medyczne w ocenie etyki katolickiej, Częstochowa 1986.

${ }_{66}$ Por. A. Kalinowska, Ekologia wybór na nowe stulecie, Warszawa 2002; M. Grzegorczyk, J. Perzanowska, Z. J. Kijas, Z. Mirek (red.), Mówić o ochronie przyrody, Kraków 2002; T. Borys (red.), Rola wyższych uczelni w edukacji dla ekorozwoju, Białystok 2003. 
ny, sozologiczny i społeczny. Zatem w tak rozumianej edukacji środowiskowej należy uwzględnić, zarówno w procesie nauczania, jak i wychowania, podstawową informację dotyczącą systemów żywych prostych i złożonych, elementów abiotycznych środowiska, sposobów i środków ochrony wszystkich elementów środowiskowych oraz znaczenia środowiska społecznego dla całego procesu edukacji środowiskowej. W edukacji ekologicznej bardzo ważną rolę mają tak zwane nauki ekologiczne, które dostarczają nam podstawowej informacji naukowej z wielu ważnych obszarów wchodzących w istotną strukturę środowiska. Czy nauki te można nazywać dziedziną nauk ekologicznych? Prawdopodobnie z czasem należy udzielić uzasadnionej pozytywnej odpowiedzi. Dzisiaj mamy cały szereg nauk ekologicznych, o których informacje powyżej zamieszczono. Ponadto edukacyjna problematyka $^{67}$ dotyczy przede wszystkim podstaw filozoficznych wychowania proekologicznego, a ściślej mówiąc wychowania sozologicznego w rodzinie, w szkole, w masmediach, w organizacjach społecznych, religiach oraz w ogólnej edukacji narodowej. Kształtowanie świadomości wrażliwej na wartość środowiska społeczno-przyrodniczego zależy również od programów nauczania w przedszkolach, szkołach podstawowych, średnich i na uczelniach wyższych oraz od powszechnej edukacji ekologicznej dorosłych. Ponadto jest to zadanie dla wszystkich zdających sprawę z jakości aktualnego środowiska i jego wpływu na życie na naszej planecie oraz z jego wpływu na życie i zdrowie człowieka w naszej Ojczyźnie, jak i na całym świecie. Jest to zadanie nie tylko dla filozofów - jak pisze M. Barnier ${ }^{68}$ - ale dla wszystkich mających wpływ na świadomość społeczną w Polsce i w świecie. Problematykę tę można włączyć do specjalności pedagogiki jako pedagogika ekologiczna lub - jak to proponuje Z. T. Wierzbicki w przygotowanej do druku pracy: Sozo-ekologia społeczna-sozo-ekopedagogika.

19. Kultura ekologiczna. Żeby zaistniała ,kultura ekologiczna” w danym społeczeństwie, w pełnym tego wyrażenia znaczeniu, to musi dokonać się wiele zmian w zasadniczych elementach kultury, a mianowicie: w nauce, technice i technologii, sztuce i religii. Zastanówmy się nad zmianami, jakie zaszły i zachodzą w tych wymienionych elementach kultury ${ }^{69}$.

${ }^{67}$ Zob. przypis nr 29.

${ }^{68}$ M. Barnier, dz. cyt., s. 9.

${ }^{69}$ Por. J. L. Krakowiak, J. M. Dołęga (red.), dz. cyt.; J. L. Krakowiak (red.), Ekologia ducha, Warszawa 1999; H. Skolimowski, Święte siedlisko człowieka, Warszawa 1999; A. Papuziński, Świadomość ekologiczna a kultura, w: A. Papuziński (red.), Wprowadzenie, s. 156-218; J. Kuczyński, Ogrodnicy świata. Wstęp do uniwersalizmu, t. 1, Warszawa 1998; J. M. Dołęga (red.), Podstawy kultury ekologicznej, Warszawa 2002; J. Nikitorowicz, M. Sobecki, D. Misiejuk (red.), Kultury tradycyjne a kultura globalna, Białystok 2001; J. M. Dołęga, Religia istotnym 


\section{Zamiast zakończenia}

Rozwój sozologii, ekofilozofii i nauk środowiskowych zależy od określonych i realizowanych badań z zakresu środowiska człowieka w skali międzynarodowej i krajowej. Międzynarodowe prace sozologiczne opierają się na dyspozycjach i programach działania organizacji międzynarodowych, takich jak: ONZ, FAO, UNESCO i wielu innych. Natomiast badania naukowe z zakresu sozologii w Polsce zostały określone już w uchwałach II Kongresu Nauki Polskiej, na którym na jednej płaszczyźnie stawiano zagadnienie produkcji i ochrony środowiska. Jest to interesująca wzmianka, zwłaszcza na czasy, w których odbywał się Kongres. Natomiast badania z zakresu ekofilozofii stają się podstawą filozoficzną do zagadnień sozologicznych oraz podstaw do filozofii nauk środowiskowych.

Każda nowa nauka domaga się rozstrzygnięcia wielu kwestii epistemologicznych i metodologicznych. Zadania te wyznaczają jeden z kierunków badań prowadzonych w ramach nauk środowiskowych. Opracowanie zagadnień epistemologicznych i metodologicznych sozologii i ekofilozofii oraz nauk środowiskowych warunkuje ich autonomiczność i jednoznaczne rozwiązywanie problemów merytorycznych z zakresu ochrony społeczno-przyrodniczego środowiska człowieka. Wprowadzenie do klasyfikacji w polskiej nauce dyscypliny naukowej sozologii (nauki o ochronie środowiska) i (lub) dziedziny nauk środowiskowych wzmocniłoby badania naukowe $\mathrm{z}$ tego zakresu oraz dałoby podstawy teoretyczne do działań praktycznych w ochronie środowiska (jak wiadomo, ochrona środowiska to również wielki dział gospodarki narodowej i międzynarodowej).

Rozwiązanie wielu problemów sozologicznych jest jednak uzależnione od sozologii i jej wielorakich związków z naukami medycznymi, biologicznymi, geologicznymi, technicznymi, ekonomicznymi, prawnymi, społeczny$\mathrm{mi}$, humanistycznymi, filozoficznymi i teologicznymi ${ }^{70}$. Osiągnięcia w tych naukach determinują pytania i odpowiedzi z nauk środowiskowych.

elementem kultury, w: M. Skierkowski (red.), Chrześcijaństwo w kontekście judaizmu i islamu, Warszawa 2003, s. 27-36.

${ }^{70}$ Por. Zadania nauki $w$ dziedzinie racjonalnego ksztaltowania środowiska człowieka, Wrocław 1974, s. 40-88; J. J. Nowak, Prawodawstwo ochrony przyrody i środowiska życiowego człowieka w Polsce, w: W. Szafer (red.), dz. cyt., s. 123-140; B. Hałaczek, M. Lubański, Filozoficzne aspekty ekologii, „Chrześcijanin a współczesność” 5 (1988), s. 11-17; F. Rosiński, Odpowiedzialność moralna za ochronę środowiska, „Chrześcijanin a współczesność” 5 (1988), s. 18-27; A. L. Szafrański, Ochrona środowiska w świetle teologii, „Chrześcijanin a współczesność" 5 (1988), s. 4-10; J.J. Skoczylas, dz. cyt.. 


\section{Environmental Sciences at the Beginning of the $21^{\text {st }}$ Century (Summary)}

The article presents the analysis of basic terms, concepts, ideas, the methodological and content-related issues of ecophilosophy and sozology. The issues connected with sozology are focused on the concept of systemic sozology, epistemology of systemic sozology, the methodology of systemic sozology, the main issues and the research specifics of the systemic sozology. The third part of the paper is devoted to environmental sciences, taught at universities as lectures or monographs: ecology, human ecology, social ecology, the ecology of the human family, sozology, sozosocial ecology, sozo-technology, sozo-economy, environmental ethics, bio-ethics, environmental legislation, eco-philosophy, eco-theology, environmental policy, ecological psychology, eco-medicine, environmental education, and ecological culture. 